\title{
Violations of the right to the city for women with disabilities in peripheral rural communities in Hungary ${ }^{\text {is }}$
}

\author{
Sz. Fabula ${ }^{\mathrm{a}, *}$, J. Timár ${ }^{\mathrm{b}}$ \\ a Department of Economic and Social Geography, University of Szeged, Hungary \\ ${ }^{\mathrm{b}}$ Centre for Economic and Regional Studies, Hungarian Academy of Sciences, Department of Social and Economic Geography, Eötvös Loránd University, Hungary
}

\section{A R T I C LE INFO}

Keywords:

Right to the city

Gender

Disability

Urban-rural inequality

Intersectionality

Central and Eastern Europe

\begin{abstract}
A B S T R A C T
The denial of the right to the city for various social groups is well documented in academic discourses. How ever, these debates lack sufficient attention to intersecting axes of social disadvantage. Furthermore, most of the relevant studies apply definitions of the right to the city that are based on urban inhabitance. In Hungary, and in other Central and Eastern European countries, where urban-rural inequalities are still obvious manifestations of uneven spatial development, we should also concentrate on the right to the city of those who inhabit rural communities.

In this study, we address the following research question: how does the right to the city (as a universal human right) apply to rural women who experience multiple social disadvantage? We argue that within the framework of the concept of the right to the city, people's basic needs and the fact that certain social groups cannot exercise their right to fundamental urban resources should not be downplayed. We also argue that the curtailment of the right to the city is not universal among rural dwellers, and this disadvantage does not affect each of these people to the same extent and in the same ways. There is a considerable diversity in how the limitation of the right to urban resources manifests itself and how disadvantaged rural residents experience it (due to e.g. intersecting axes of oppression/identities). Our empirical study is based on interviews conducted with 32 disabled or chronically ill women living in Hungarian rural areas. The focus is on their perceptions of their everyday lives and reflections on their problems regarding the access to urban resources and services. According to the interviews, urban-rural divide and patriarchal and ableist power relations contribute to the violations of disabled women's right to the city.
\end{abstract}

\section{Introduction}

The use of feminist research approaches, it can be argued, has made one of the biggest contributions to the development of the right to the city' concept proposed by Lefebvre (1968 [1996]). We agree with Fenster's (2005a, 2005b, 2010, p. 229) critique of Lefebvre's original idea in two respects: i) the discourse on patriarchal power relations should be incorporated into the conceptualisation of the right to the city; ii) 'the gendered right to the city' always intersects with other identity issues.

This critique serves as the starting point of our study but we also revisit Lefebvre's - and Harvey's (2008) - concept on the right to the city. In our view, it is mainly this concept which places the right to the city in the context of links between the city (urbanisation/the urban process/production of urban space) and global capitalism, and which also pays sufficient attention to the relationship between the urban and the rural. Indeed, in many parts of Hungary - and in Central and Eastern Europe in general - the fading of the urban-rural distinction (Lefebvre, 1970 [2003]; Harvey, 2008; Brenner \& Schmid, 2011, 2015) has not become a reality for less privileged social groups. In these regions the urban-rural divide is still one of the most apparent manifestations of uneven development, resulting in considerable social inequalities. Furthermore, while the right to the city is far more than the individual liberty to access urban resources' (Harvey, 2008, p. 23), the question could also be asked whether it is only relevant for those who inhabit the city. Since the differences between the urban and the rural have not vanished, and the urban lifestyle [Lefebvre, 1968 (1996)] has

\footnotetext{
मे 'Gendering the right to the city: appropriation and participation'Cities - The International Journal of Urban Policy and Planning

* Corresponding author at: Department of Economic and Social Geography, University of Szeged, 2 Egyetem utca, Szeged H-6722, Hungary.

Email address: fabula.szabolcs@gmail.com (Sz. Fabula)
} 
not become a universal feature of Hungarian society, we believe that the focus of the right to the city cannot be limited to urban inhabitants. As we agree that the right to the city is a collective human right (Harvey, 2008), we think that urban resources should be accessible to everyone and not only to those in urban areas.

Bearing these issues in mind, we address the following research question in this paper: how does the right to the city (as a universal human right) apply to rural women who experience multiple social disadvantages? To answer this question we highlight the main results of interviews conducted with women living with disabilities in peripheral rural areas in Hungary. Our aim is twofold: first, to understand these people's relationships to the city through their perceptions of their everyday lives and reflections on their problems regarding access to urban resources; and second, to contribute to theoretical debates about the right to the city. Although we agree with the broader definition of the right to the city described above (see Harvey, 2008), we argue that even within the framework of such a broader concept, people's very basic needs and the fact that certain social groups cannot exercise their right to fundamental urban resources should not be downplayed. Furthermore, we argue that the curtailment of the right to the city is not universal among rural dwellers, and this phenomenon does not affect each of these people to the same extent and in the same ways because their group is not homogenous. There is a considerable diversity in how the limitation of the right to urban resources manifests itself and how disadvantaged rural residents experience it (due to intersecting identities and systems of oppression).

This paper is divided into three main parts. In the first part we explore how a broad understanding of the gendered right to the city applies to a range of marginal groups, including those who are not urban inhabitants. The second part briefly outlines the background to the qualitative research based on 32 interviews we conducted in rural areas in Hungary. In the third section disabled women's narratives are analysed to highlight the everyday manifestations of the curtailment of their right to the city in the context of their intersecting gender, disabled and rural identities.

\section{Some theoretical reflections on the concept of the right to the city}

To support our main arguments, in this section we critically analyse and challenge the right to the city concept from the point of view of rural disabled women. For this purpose, we focus on two aspects of the concept that are emerging in academic discourse: (i) 'who' the right to the city can be exercised by and (ii) 'where' the right to the city can be exercised.

According to Lefebvre's concept, the right to participation is as important as the right to appropriation, and the former must prevail not only in democratic decision-making but also in every aspect of the production of urban space (Lefebvre, 1968 [1996]; Purcell, 2002). Furthermore, when Harvey (2012, p. 4) argues that the right to the city is 'far more than a right of individual or group access to the resources that the city embodies', he refers to a 'collective power over the process of urbanisation': 'Since the urban process is a major channel of use [of the surplus], then the right to the city is constituted by establishing democratic control over the deployment of the surpluses through urbanisation' (2012, pp. 22-23).

Today the right to appropriation, participation and control do not seem to be fundamental human rights but privileges of the powerful. Such inequalities are well indicated by the fact that within academic discourse one of the most frequent themes is 'whose right to the city'. A number of groups, such as the homeless (Mitchell, 2003; Núñez, 2010), immigrants and ethnic minorities (Dikeç, 2002) and sexual minorities (Hubbard, 2013) are experiencing high degrees of exclusion. Recent studies have also highlighted the curtailment of the right to the city of urban women (Buckingham, 2010; Fenster, 2005a, 2005b, 2010), rural-to-urban migrant women (Secor, 2003) and people with disabilities (Bezmez, 2013; Harold, 2013) as outcomes of patriarchal social relations and ableism. Moreover, there is a considerable literature about the effects of ableist power geometries on women living with disability in Western urban societies (Anderson \& Kitchin, 2000; Crooks \& Chouinard, 2006).

The right to the city may also be pertinent for those who do not inhabit the city but who wish to access the multiple urban resources. Although Lefebvre (1989 [2014]) argued that capitalist industrialisation was dissolving the city as a bounded entity and would eventually obliterate the urban-rural distinction 'into a set of porous spaces of uneven development under the hegemonic command of capital and the state' (Harvey, 2008, p. 36), and the rural has been profoundly transformed, the disparities between the urban and the rural may remain very sharp, especially for those with limited mobility and material resources. Furthermore, recent studies - applying administrative or functional territorial definitions of 'the rural' - have demonstrated the existence of inequalities between urban and rural areas in Hungary with respect to, for example, income (Pénzes, Pálóczi, \& Pásztor, 2014), labour-market opportunities (Bihari \& Kovács, 2005), the availability of public services (Nikitscher \& Velkey, 2012) and the level of well-being (Nagy \& Koós, 2014). It can be concluded that many rural areas in Hungary are 'disadvantaged' regions, characterised by the concentration of socio-economic problems and conflicts, and even by ghetto formation in some cases (Virág, 2006). Although, according to Lefebvre, the right to the city is a normative category based on inhabitance (Fenster, 2010; Iveson, 2013), he also suggested that the holder of this right is the whole of society (Lefebvre, 1968 [1996]). This generalisation is important since for him the urban does not pertain to the traditional or the existing city but to a future city, to a place in which the city-country hierarchical distinction will disappear (Marcuse, 2009, 2014).

In this study we draw attention to those social groups that - under the conditions of current social reproduction, characterised by capitalist, patriarchal and ableist relations - are mostly excluded from the 'urban process' described by Lefebvre (1968 [1996]) or from the 'planetary urbanisation' described by Brenner and Schmid (2011, 2015). We wish to challenge the demarcation which stems from the approach that limits the right to the city to the territory of the 'city as a spatial unit'. We argue that if attention is not paid to those living on the 'dark side' of the uneven development at an urban-rural scale (Harvey, 2008), thus excluding them from our discourses, then we contribute to the reproduction of existing inequalities.

In this paper we focus on people who are affected by both patriarchal and ableist relations, with special attention to those everyday practices and struggles which are rooted in uneven urban-rural development. By doing so, we hope that our study will also contribute to the right to the city concept: the broader concept of the right to the city proposed above is extended to rural areas and it emphasises the importance of control but does not downplay the importance of accessibility to urban resources. Besides, from a gendered perspective, our study will not only add another - hitherto neglected - group to the discourse, but it will also deepen our understanding of the effects of intersecting oppressive social relations on rights. As we study rural disabled women's discourses and practices in and through which relational, fluid and changing identities are mutually and continuously (re)constructed and as we also wish to understand multiple structures of subordination and inequalities, we apply the idea of the complexity of intersectionality both in a conceptual and a theoretical sense (McDowell, 2008). Paraphrasing McDowell (2008, p. 505), we believe that combining the understanding of 'the specificities of different lived experiences with the commonalities' of the varied manifestations of the violations 
of the right to the city 'is an essential part of feminist politics', thus our empirical analysis is also based on this way of thinking.

\section{Research method and contextual information}

This study is based on interviews conducted with 32 disabled or chronically ill women living in Hungarian rural areas. The interviews were undertaken within the framework of various research projects ${ }^{1}$ between July 2010 and August 2015. Regarding their type, each interview is a life-course interview combined with a semi-structured conversation. These interviews did not specifically target the issue of the right to the city, which is a major limitation of our methodology since our insights into the respondents' relationships to the city might remain incomplete. Nevertheless, a notable advantage is that in this way we did not structure the respondents' narratives, but instead they could focus on those topics which they found the most important. In the analysis, we paid special attention to those parts of the interviews in which the respondents made explicit or implicit references to the city.

The interview partners were recruited through two main channels. Firstly, various institutions (e.g. in health care, sheltered employment ${ }^{2}$ ) served as entry points and mediated between us and the interview partners. Secondly, 'snowball sampling' was employed in some cases, as friendship and neighbourhood ties were mobilised to contact potential respondents. The largest number of the interviewees belongs to the 50-59 age group (19), while eight people are younger than 50 and five persons are older than 59. Among the respondents 18 are married or have a permanent partner, nine are divorced, three are widowed and two persons are single. Most of them have multiple health impairments: 17 people have some kind of internal organ disease or chronic illness; 14 live with mobility impairment; 6 people reported mental health problems and 1 person is visually impaired. Three interviewees do not have such health conditions, but are carers of disabled or ill family members and therefore they provided relevant information for our study.

We have thus concentrated on social groups that are not part of 'urban life' and consequently the interview partners were recruited from economically backward rural micro-regions, from villages and small towns where there is a lack of public services (e.g. special health care services, or a local administrative office of the Hungarian government) that can be found in larger urban centres.

\section{Rural disabled women's relationships to the city - main results of the interviews}

In this section we analyse disabled women's experiences of the violations of their right to the city. Although this topic was not directly targeted by the interviews, the respondents' connections to the city came up in two main ways during the conversations. On the one hand, they mainly interpreted their everyday life experiences in the contexts of their own rural communities, which were often compared to their

\footnotetext{
1 Some interviews were conducted in research projects funded by the EU and Hungarian Central Government (SEMIGRA-ESPON 2013 EU Programme, 'Rural transformations in Hungary' - Ministry of Rural Development /2012-2013/, Hungarian National Scientific Research Fund/OTKA 109269) and their original focus was socio-spatial peripheralisation; while the other part of the interviews represents the $\mathrm{PhD}$ research of the first author of this paper.

2 The term 'sheltered employment' refers to the special employment of people with disabilities. According to Hungarian regulations, sheltered workplaces can be run by private companies as well as local municipalities, but in each case the employment is subsidised by the central government. At these workplaces the employees (people with disabilities) mainly produce handicraft goods (e.g. toys, smaller household tools) or do other - physically and mentally not too demanding - activities which support their rehabilitation.
}

perceptions of the nearby towns in particular and to urban life in general. On the other hand, when systematically asked about their inter-settlement connections, they gave detailed information about how and for what purposes they used urban spaces. We identified three main dimensions of their relationship to the city, according to which this section of the paper is organised: (1) paid employment, (2) services (particularly health care) and (3) housing market and financial services. In each sub-section, various dimensions of the interview partners' multiple disadvantages (identity) are presented simultaneously and in different constellations (intersectionality).

\subsection{The city as the main locus of paid work}

Paid work has utmost importance to the interview partners since most of them have a low socioeconomic status, and so any work-related income can be life-saving in their everyday struggle to make a living. However, finding a suitable job can be very difficult for these rural women, as shown by the career history of $\mathrm{Jane}^{3}$ ( 53 years old, living with spinal injury and multiple diseases of the internal organs):

“...after [primary] school I worked in agriculture. Then I was on maternity leave with the kids. I was at home raising animals as a small holder, then with two children I became a full-time mother because I couldn't go back to work. After that I was pensioned off as a disabled person. ... I stayed at home, nurturing the kids and keeping livestock... I couldn't work [elsewhere/in the city] anyway. I cannot bear travelling by bus; only with pills [analgesic]. And here, in this village, where [can I go to work]?".

In the case of Jane, the problem of women's 'double burden' (career vs. child care) is exacerbated by the problem of disability, making it impossible for her to work in the city. Such experiences are quite common among rural people with disabilities in Hungary (see e.g. Simonyi, 2002).

As with Jane, rural women in Hungary in general have to face multiple disadvantages. First, their chances of being employed are considerably lower than those of rural men and urban women (Timár, 2005). There is also convincing evidence of the marginality associated with gender roles, as women who commit to having children often experience discrimination in the primary labour market. In terms of the breadwinner role in rural families with children, the employment rate of mothers is significantly lower than that of fathers; among mothers the number of those leaving the labour market exceeds the number of the officially employed (Laki, 2007). Moreover, many mothers who can get a job outside of their place of residence face the difficulties of commuting because there is a lack of child care institutions in their own communities (Nagy, Timár, Nagy, \& Velkey, 2015; Timár \& Velkey, 2016). According to recent studies, both gender roles and social isolation can worsen the living conditions of rural women. For example, being a widow, on maternity leave or a homemaker significantly increases the risk of impoverishment (Kovách, 2012; Spéder, 1997). To conclude, rural women's access to urban resources and social participation is clearly hindered by patriarchal power relations in Hungary.

Disability can be another source of labour-market disadvantage for rural women. As the interviews demonstrate, without an appropriate workplace environment, the health condition of these persons can seriously affect their work performance or even their commuting opportunities. For example, Cynthia (59, spinal disorder, arthritis and depression) had been searching for a job in the neighbouring town:

\footnotetext{
3 All the interviews were taken in the Hungarian language and the quotations in this paper were directly translated by the authors. To ensure anonymity, pseudonyms are used when quoting interview partners.
} 
"I was asking about job opportunities in Orosháza [nearby town] well, actually it was my daughter who asked, as she worked there at the municipal hospital - for a caretaker or dispatcher job, or something. But they preferred pensioners or people who had already worked there before... I cannot do heavy physical work, and the truth is that there is rarely any job here [in my village]".

Cynthia's story has some lessons that go well beyond the marginalisation experienced by rural inhabitants with disabilities in urban labour markets because of the interests of capital (private employers). Her narrative also sheds light on some negative outcomes of state regulations. For example, in public institutions workers are often employed even after the age of retirement, since the labour costs for those people are significantly lower (due to state regulations) than that of working-age applicants. In addition, the local municipality-led public employment service - which Cynthia was willing to accept - is only available for the officially unemployed, but not for those who are on a disability pension (no matter how small an amount of money they receive).

It seems that a particularly important source of the many-faceted labour-market marginality is uneven development and the economic backwardness of rural regions. For instance, Paula (45, asthma sufferer), a single mother of two children living in a village of 3000 inhabitants, is convinced that her illness developed during her former job (due to dust pollution in a textile factory), and the pregnancies also contributed to her health situation. Nevertheless, she basically interprets employment problems as a dimension of urban-rural inequality:

"...the problem is the same as in every small village, that there are no jobs; no employment opportunities and no opportunities at all. If there were jobs, there would be more opportunities as well. So this is why life here is a little hard. And anywhere you would apply for a job, employers prefer local labour. I think this is the case everywhere, but maybe chances are better in the city".

The lack of job opportunities in rural areas is only one side of the coin; another problem is that those living outside of the city have a difficult access to urban labour markets (Bihari \& Kovács, 2005). Besides the inequalities caused by patriarchal and ableist power geometries, these rural residents are also disadvantaged by employers who do not contribute to commuting costs, or by the economic structure which excludes unskilled and less skilled people. Although each interview partner's personal disadvantage is special to some extent, the above examples demonstrate that in the curtailment of the right to the city of rural women with disabilities (in terms of their access to urban labour markets) urban-rural inequality is a critical factor.

\subsection{The city as a place of service provision}

Another aspect of the interviewed women's relationship to the city is the availability of urban services. For most of these people, the use of urban health care facilities is the primary manifestation of their connection with urban areas. According to our research findings, they can use many services in the nearest towns but for more specific treatments they have to travel to the regional centre or even farther. Such journeys can place a heavy burden on these people and their families. The most frequently mentioned causes behind limited mobility were low income, the lack of supportive relationships and their own health status. Laura (53, disease of the internal organs) gave us some examples of such obstacles:

"I visit Gyula [a county health centre] every two weeks to get this infusion treatment and then for two or two and a half months the symptoms are quite bearable. I mean my hands do not go numb so often and my headaches are not so heavy. Sometimes it happens that I cannot feel my legs and I do not feel where I step...usually if my husband has time he gives me a lift, for example to the doctor or to go shopping. We go together by car and that makes it easier".

From Laura's story, it turns out that she can rely on a supportive family network and a private car to gain access to urban health services. However, not all interview partners can deploy such resources. In addition, depending on the help of other people makes these women quite vulnerable in their everyday lives.

Such findings have considerable importance as far as disabled people's right to the city is concerned. Recent studies from various countries suggest that in rural areas health care service provision and residents' access to appropriate medical treatment fall well short of the allocation of health care in urban centres (Jordan, Roderick, Martin, \& Barnett, 2004; Wong \& Regan, 2009). Regarding the situation in Hungary, the average proportion of disabled and chronically ill people in the local population in rural communities is higher than in urban areas, and the incidence of stress- and work-related impairments is particularly high in rural regions (Andorka, 1996; Váradi, 2008). In addition, significant inequalities and a sharp urban-rural divide exist in access to health services, and the situation is worsened by regional patterns of economic development (Pál, 1996).

For many interview partners, disability identity mainly manifests itself in the use of health care services but health-related disadvantages are often exacerbated by other oppressive social relations. For instance, class inequality (e.g. as is the case for poor people, both service prices and travel costs contribute to their exclusion from high-quality care) or patriarchy can be detected even in health care institutions. Susan's (57, mobility impaired - paralytic poliomyelitis) narrative well demonstrates the possible effects of the co-existence of such factors on rural women with disabilities:

“...I went to a gynaecological cancer screening service - they always recommend it - but I couldn't get onto the examination table. Then the assistants turned their back on me and I didn't understand why. I am not a rude person, but I had to ask for help because I could not climb onto the table without help".

For Susan - similar to several other women - even gynaecological treatments are unavailable in her rural community. Since she was discriminated against during the above-mentioned medical examination due to her identities as a woman and as a disabled person, she felt the need to find a gynaecologist in another town. From Susan's story it can be seen that making an urban health facility physically accessible for the inhabitants of hinterland settlements is not always enough. The masculinist and ableist social environment of such institutions can also be exclusionary.

It can be concluded that the interview partners' right to the city is violated with respect to the use of health services. This is partly rooted in structural relations as in Hungary there are considerable inequalities in the population's health status and in health care provision between urban and rural areas, and especially between core and peripheral regions (Pál, 2017). Furthermore, as the above examples demonstrate, disabled women's poor access to health care is exacerbated by their mobility obstacles which are rooted in other disadvantages such as low income or the lack of supportive social networks.

\subsection{The urban housing market and the city as a provider of financial resources}

For several interview partners the only way to resist the disadvantages of rural life and the exclusion from the use of urban facilities is by moving to the city and becoming an urban resident. Nevertheless, the relocation of these women to urban areas can be hindered by various factors. For example, in their villages - similar to many other rural areas in Hungary - houses are almost unsellable due to the stagnation 
of local property markets (see also: Nagy et al., 2015; Timár \& Velkey, 2016), and housing prices in urban centres are significantly higher. As Katie (56, disorders of the locomotor and respiratory systems) explained:

"... after the divorce... my brothers called me to move back to Csaba [the county seat], but I couldn't afford a house there. Here in this village I had better chances... I bought a house, small enough that I could maintain it. But I wouldn't have had such an opportunity in Csaba".

Although Katie basically likes her current place of residence, it is difficult in her situation to make a decent living in the village. Other respondents explicitly declared the intention of leaving but they could not pay higher urban housing prices. Their problems are aggravated by the fact that they cannot mobilise additional financial resources. As Paula noted, it is particularly hard for those "who raise children alone, since borrowing money nowadays is quite risky".

As for financial support, for instance anti-poverty welfare benefits, location is important: factors such as the available resources of local municipalities or the attitudes of decision-makers can have a considerable influence. This is demonstrated by the story of Cynthia:

"I submitted an application [for support] in Orosháza [nearby town] but it was rejected as I am not an Orosháza resident. That was some Family Support Service stuff. Local residents of that town are eligible for a non-refundable payment. So I gave it a try... but since I live in Pusztaföldvár, I don't get such kind of support."

It seems that Cynthia is in a disadvantaged situation due to her place of residence, since the municipality of her village does not provide financial support for the local inhabitants as does the nearby town. Later during the interview she also noted that moving to the town would not be a real option for her: "if I sold my little house, I would get 2 million (HUF, approx. 66,450 ). In Orosháza, an apartment cannot be purchased for that money" (Cynthia). To conclude, in the case of our interview partners, the class-based exclusionary character of housing markets is exacerbated by the urban-rural divide and the devaluation of rural properties. These results demonstrate that the respondents' right to the city which can also be defined (following Lefebvre and Harvey) as the right to the production of urban space - is inevitably violated since even their right to urban property can hardly be exercised because of rural disadvantage which intersects with other systems of oppression (e.g. ableism, class, patriarchy).

\subsection{The intersections of gender, disability and rural-urban relations in the respondents' everyday lives}

It can be seen that ableist and patriarchal power relations and urban-rural inequalities violate the respondents' right to the city by limiting their access to urban resources. It is also clear that these axes of oppression do not work independently from each other. However, the interviews have shown that rural women with disabilities can experience the coexistence of these disadvantages in very different ways, according to their varied identities and socio-spatial contexts.

Most of the interviewed women talked about disadvantages rooted in gender roles less explicitly than about subordination related to disability. One of the main reasons behind this phenomenon can be the neglect of the topic of gender inequalities in public discourses. In Hungary, feminism - as in CEE in general - still has a negative connotation (Timár, 2005). Nevertheless, some respondents even ranked the various disadvantages:

"Well, frankly, my employment situation did not become disadvantageous because of my disability. The fact that I am a rural resident was a bigger problem" (Irene, 55, diseases of the internal organs).
Since these women cannot solve the problems of their villages, the only workable option for them is migrating to the city. ${ }^{4}$ Therefore, they try to improve their personal situations. During these struggles, they sometimes subject themselves to a certain type of subordination, in order to mitigate another type. Some of them take a traditional gender role (full-time mother) to combat their unemployment-related problems (Jane). Others - in contrast to those who reject a disability identity - try to improve their class situation by applying for an official 'disabled' status. ${ }^{5}$ Dianna (44, injured in a traffic accident and has multiple diseases of the internal organs) briefly described the process:

"There was the accident, and after that I requested the categorisation process $^{6}$ on myself on my GP's advice. I thought 'okay, let's have a try. There is nothing to lose'. So I gave it a shot. I did not want to be a pensioner. At least I did not want it in that way. Therefore, I have disabled status but it is not a direct outcome of my accident. For me this was not the only issue, but my injury came and then I did not see another way forward".

Still others accept even low-paid jobs at rural sheltered workplaces (available only for people with disabilities) because of their exclusion from urban primary labour markets. However, by such a strategy they can easily fall into the role of the exploited worker, such as Inge (60, mental health problem):

"During my whole summer in 2009 I came at 8 in the morning... I came for half past 7 and went home at 8 in the evening. ... We worked overtime. And that had to be concealed. We were told not to try to talk about that".

Furthermore, many of these workplaces provide quite precarious job opportunities: contracts are fixed-term and can be obtained only on the basis of official disability categorisation.

However, the above examples are only the personal struggles of the interviewed women. The level of their political and civil activity is extremely low, which is another post-socialist characteristic of Hungarian society. Some of them acknowledge and even try to contest group-based social oppression, but the success of resistance depends not only on the intentions and efforts of these people. Personal identities and experiences are important, but it should be borne in mind that the social disadvantages of disabled and chronically ill women are also determined by structural factors, for example the intersections of patriarchal and ableist relations and urban-rural inequality.

\section{Conclusions}

This paper demonstrates that geography matters in the right to the city. It is not only the differences between neighbourhoods within cities in different countries but - we argue - also the inequalities within a country that give particular relevance to geographical perspectives. In a Central and Eastern European context, for example, when examining the right to the city from a rural viewpoint, we can even recognise the lack of a basic right to urban resources.

It can also be concluded that intersectionality is an important issue as far as the everyday experiences of particular social groups are con-

\footnotetext{
4 Another issue is that through this out-migration they can also contribute to the marginalisation of their village, and the question can be raised how they as new urban 'citizens' can exercise their right to the city (see an example written by Secor, 2003).

5 In Hungary, disabled status is an official status defined by the central state. It has several sub-categories, but in general, people labelled as 'disabled/living with disability' are eligible for certain special benefits and services.

6 In Hungary, the level of health damage and disability of impaired and chronically ill persons is assessed by official medical expert committees. These committees also set out the categories according to which disability welfare benefits are granted.
} 
cerned. Each person has multiple identities and they can use and perceive the city in many different ways. In addition, our empirical analysis showed that violation of people's right to the city can be manifested in several forms according to the axes of social relations, for example gender, disability and the rural-urban divide.

It is clear that patriarchal relations and ableism in society has seriously curtailed the right to the city of the interviewed disabled and chronically ill women. Nevertheless, several respondents suggested that capitalism's uneven development at the rural-urban scale can have more serious effects on their lives. Moreover, some of them thought that living in a rural area was the primary source of their disadvantages.

Finally, taking the experiences of the interviews into consideration, we argue that the respondents are excluded from control of the urban process. As a matter of fact, they barely talked about this issue during the interviews, a 'silence' that can be rooted in their lack of basic assets and resources, and also in the weakness of Hungarian civil society. We believe that the concept of the right to the city can contribute to the understanding of the marginalisation of disadvantaged social groups such as rural women with disabilities. In addition, we hope that our study demonstrates that it is worthwhile to use the concept in the broader understanding that we propose. Harvey's (2012) concept suggests that some social groups are subjects of a class-based exclusion from power over the process of urbanisation, as they cannot exercise democratic control over the deployment of the surpluses generated by urbanisation. Feminist critiques of the concept point to the fact that patriarchal power relations limit urban women's participation in democratic decision-making, and in the production of urban space in general. Judging by our current knowledge, it has not yet been emphasised that certain social groups can be excluded from the collective power to which the right to the city is attributed based on their place of residence. In countries where urban-rural inequalities still markedly exist, these inequalities exacerbated by other oppressive systems, such as patriarchy and ableism - can exclude rural inhabitants from the urban process. We agree with those who see the right to the city as a collective right to the production of urban space. Although in this study there is a strong focus on access to urban resources and services, we do not see the right to the city as a 'visiting right or as a return to traditional cities' (Lefebvre, 1968 [1996], p. 158). Nevertheless, our intention is to emphasise that for certain social groups even visiting the city is still severely hampered and thus the right to the city - as a collective human right - cannot prevail.

\section{Acknowledgments}

We would like to express our special thanks to Eleonore Kofman and Elena Vacchelli for their very detailed suggestions and for their support throughout the process of preparing this paper. We would also like to thank the unknown reviewers for their useful comments and constructive critiques. Last but not least, we would like to thank all the interview partners for sharing their views and so contributing to our study, and EU and Hungarian Institutions for funding this research (see Footnote $1)$.

\section{References}

Anderson, P., Kitchin, R., 2000. Disability, space and sexuality: Access to family planning services. Social Science \& Medicine 51 (8), 1163-1173.

Andorka, R., 1996. A társadalmi jelzószámok tükrében [In the mirror of social indicators]. In: Kolosi, T., Andorka, R., Vukovich, G. (Eds.), Társadalmi Riport 1996. Budapest, TÁRKI, pp. 16-43.

Bezmez, D., 2013. Urban citizenship, the right to the city and politics of disability in Istanbul. International Journal of Urban and Regional Research 37 (1), 93-114.

Bihari, Z., Kovács, K., 2005. Slopes and slides: Spatial inequalities in employment opportunities at the turn of the millennium. In: Barta, G., Fekete, É.G., Kukorelli
Szörényiné, I., Timár, J. (Eds.), Hungarian spaces and places: Patterns of transition. Pécs, Centre for Regional Studies, pp. 360-377.

Brenner, N., Schmid, C., 2011. Planetary urbanisation. In: Gandy, M. (Ed.), Urban constellations. Jovis, Berlin, pp. 10-13.

Brenner, N., Schmid, C., 2015. Towards a new epistemology of the urban?. City 19 (2-3) 151-182.

Buckingham, S., 2010. Examining the right to the city from a gender perspective. In: Sugranyes, A., Mathivet, C. (Eds.), Cities for all. Proposals and experiences towards the right to the city. Habitat International Coalition, HIC, Santiago, pp. 57-62.

Crooks, V.A., Chouinard, V., 2006. An embodied geography of disablement: Chronically ill women's struggles for enabling places in spaces of health care and daily life. Health \& Place 12 (3), 345-352.

Dikec, M., 2002. Police, politics, and the right to the city. GeoJournal 58 (2), 91-98.

Fenster, T., 2005. Identity issues and local governance: Women's everyday life in the city. Social Identities 11 (1), 21-36.

Fenster, T., 2005. The right to the gendered city: Different formations of belonging in everyday life. Journal of Gender Studies 14 (3), 217-231.

Fenster, T., 2010. The right to the city and gendered everyday life. In: Sugranyes, A., Math ivet, C. (Eds.), Cities for all. Proposals and experiences towards the right to the city. Habitat International Coalition, HIC, Santiago, pp. 63-76.

Harold, G., 2013. Reconsidering sound and the city: Asserting the right to the deaf-friendly city. Environment and Planning D 31 (5), 846-862.

Harvey, D., 2008. The right to the city. New Left Review 53, Retrieved from http:// newleftreview.org/II/53/david-harvey-the-right-to-the-city, (19 January 2016).

Harvey, D., 2012. Rebel cities. From the right to the city to the urban revolution. Verso, London and New York.

Hubbard, P., 2013. Kissing is not a universal right: Sexuality, law and the scales of citizenship. Geoforum 49 (6), 224-232.

Iveson, K., 2013. Cities within the city: Do-it-yourself urbanism and the right to the city. International Journal of Urban and Regional Research 37 (3), 941-956.

Jordan, H., Roderick, P., Martin, D., Barnett, S., 2004. Distance, rurality and the need for care: Access to health services in South West England. International Journal of Health Geographics 3 (21), 1-9.

Kovách, I., 2012. A vidék az ezredfordulón. A jelenkori magyar vidéki társadalom szerkezeti és hatalmi változásai [The countryside at the millenium. Recent changes in the structure and power relations of the Hungarian rural society]. Argumentum, Budapest.

Laki, I., 2007. Vidék, falvak és szegénység [Countryside, villages and poverty]. A Falu 22 (4), 17-25.

Lefebvre, H., 1968. The right to the city. In: Kofman, E., Lebas, E. (Eds.), Writing on cities. Blackwell Publishers, Oxford and Malden (MA), pp. 147-159, [1996].

Lefebvre, H., 1970. The urban revolution. University of Minnesota Press, Minneapolis and London, [2003].

Lefebvre, H., 1989. 'Dissolving city, planetary metamorphosis' (trans. by Laurent Corroyer, Marianne Potvin, Neil Brenner). Environment and Planning D 32 (2), 203-205, [2014].

Marcuse, P., 2009. From critical urban theory to the right to the city. City 13 (2-3) 185-196.

Marcuse, P., 2014. Reading the right to the city. City 18 (1), 4-9.

McDowell, L., 2008. Thinking through work: Complex inequalities, constructions of difference and trans-national migrants. Progress in Human Geography 32 (4), 491-507.

Mitchell, D., 2003. The right to the city. Social justice and the fight for public space. The Guilford Press, New York and London.

Nagy, E., Timár, J., Nagy, G., Velkey, G., 2015. The everyday practices of the reproduc tion of peripherality and marginality in Hungary. In: Lang, T., Henn, S., Ehrlich, K. Sgibnev, W. (Eds.), Understanding geographies of polarization and peripheralization. Perspectives from central and Eastern Europe and beyond. Palgrave Macmillan, Basingstoke (UK) and New York, pp. 135-155.

Nagy, G., Koós, B., 2014. First results in modelling objective well-being in Hungary at lower territorial level. Regional Statistics 4 (2), 71-86.

Nikitscher, P., Velkey, G., 2012. "Mert az iskolának maradni kell" - Közoktatási feladatellátás a Pásztói kistérségben ["Because the school must stay" - Public education in the Pásztó micro-region]. In: Balázs, , Kovács, K. (Eds.), Többcélú küzdelem: Helyzetképek a kistérségi közoktatásról. Oktatáskutató és Fejlesztô Intézet, Budapest, pp. $207-241$

Núñez, A., 2010. Homeless people fight for the right to housing, in Mar del Plata, Argentina. In: Sugranyes, A., Mathivet, C. (Eds.), Cities for all. Proposals and experiences towards the right to the city. Habitat International Coalition, HIC, Santiago, pp $149-154$.

Pál, V., 1996. A potenciális városok egészségügyi infrastruktúrájának és ellátottságának területi sajátosságai [Territorial characteristics of the health-care infrastructure and capacities of potential towns]. Tér és Társadalom 10 (2-3), 225-230.

Pál, V., 2017. Egészségünk földrajza [The geography of our health]. Magyar Tudomány 178 (3), 311-321.

Pénzes, J., Pálóczi, G., Pásztor, S., 2014. Social frontiers in Hungary in the mirror of the centre-periphery dichotomy of incomes. Eurolimes 17, 11-23.

Purcell, M., 2002. Excavating Lefebvre: The right to the city and its urban politics of the inhabitant. GeoJournal 58 (2), 99-108.

Secor, A.J., 2003. Citizenship in the city: Identity, community, and rights among women migrants to Istanbul. Urban Geography 24 (2), 147-168.

Simonyi, , 2002. Családok peremhelyzetben városon és falun [Families at the margins in towns and villages]. Szociológiai Szemle 12 (4), 131-142.

Spéder, Z., 1997. Szegény nôk és férfiak [Women and men living in poverty]. In: Lévai, K., Tóth, G. (Eds.), Szerepváltozások. Jelentés a nők helyzetéről. Budapest, TÁRKI, pp. 121-138. 
Timár, J., 2005. Gender and spatial inequalities in Hungary in the transition era. In: Barta, G., Fekete, É.G., Kukorelli Szörényiné, I., Timár, J. (Eds.), Hungarian spaces and places: Patterns of transition. Pécs, Centre for Regional Studies, pp. 307-322.

Timár, J., Velkey, G., 2016. The relevance of the political economic approach: The interpretations of the rural in the migration decision of young women and men in an economically backward region. Journal of Rural Studies 43 (1), 311-322.
Váradi, M.M., 2008. Kistelepülések lépéskényszerben [Small villages under pressure]. Új Mandátum Kiadó, Budapest.

Virág, T., 2006. The regional ghetto. Reviewing Sociology 12 (1), 51-70.

Wong, S.T., Regan, S., 2009. Patient perspectives on primary health care in rural communities: Effects of geography on access, continuity and efficiency. Rural and Remote Health 9 (1), 1-12. 